\title{
Highly efficient microcrystalline silicon solar cells deposited from a pure $\mathrm{SiH}_{4}$ flow
}

\author{
M. N. van den Donker, ${ }^{\text {a) }}$ B. Rech, and F. Finger \\ Institute of Photovoltaics, Forschungszentrum Jülich GmbH, D-52425 Jülich, Germany
}

W. M. M. Kessels and M. C. M. van de Sanden ${ }^{\text {b) }}$

Department of Applied Physics, Eindhoven University of Technology, P.O. Box 513, 5600MB Eindhoven, The Netherlands

(Received 20 June 2005; accepted 27 October 2005; published online 22 December 2005)

\begin{abstract}
A time-resolved optical emission spectroscopic study identified transient behavior of the excited $\mathrm{SiH}$ emission in a parallel plate $\mathrm{SiH}_{4} / \mathrm{H}_{2}$ plasma. The transient behavior could be prevented by filling the background gas with $\mathrm{H}_{2}$ prior to plasma ignition. Applying this condition, state-of-the-art microcrystalline silicon $(\mu c-\mathrm{Si}: \mathrm{H})$ could be deposited irrespective of the applied $\mathrm{H}_{2}$ flow, ultimately demonstrated by a $9.5 \%$ efficient solar cell deposited from pure $\mathrm{SiH}_{4}$. The results are discussed in terms of $\mathrm{SiH}_{4}$ back diffusion: an initial diffusion flux of $\mathrm{SiH}_{4}$ from the reactor's dead volume back into the plasma. (C) 2005 American Institute of Physics. [DOI: 10.1063/1.2152115]
\end{abstract}

Plasma deposition of the intrinsic microcrystalline silicon $(\mu \mathrm{c}-\mathrm{Si}: \mathrm{H})$ film is a key process in the fabrication of highly efficient thin-film silicon solar cells. High-quality $\mu \mathrm{c}-\mathrm{Si}: \mathrm{H}$ is deposited in a narrow regime close to the phase transition to amorphous growth, ${ }^{1}$ generally tuned by the feed gas dilution ratio $R=\left[\mathrm{H}_{2}\right] /\left[\mathrm{SiH}_{4}\right]$. $^{1-5}$ Commonly applied dilution ratios $(R)$ range between approximately 10 and 300 . These high values reflect the important role of $\mathrm{H}$ in the growth process. ${ }^{6}$ Nonetheless, recent studies ${ }^{7,8}$ revealed that it is possible to deposit $\mu \mathrm{c}-\mathrm{Si}: \mathrm{H}$ at much lower $R$ by using the $\mathrm{H}$ that is created upon dissociation of $\mathrm{SiH}_{4}$. However, solar cells prepared under these conditions showed poor performance. ${ }^{7}$ Roschek et al. tried to solve this by grading the process flows during deposition, ${ }^{8}$ but still could not achieve state-of-the-art devices. These studies indicated that high $R$ is an essential prerequisite for obtaining high-quality material.

In this letter, we will demonstrate that state-of-the-art $\mu \mathrm{c}-\mathrm{Si}: \mathrm{H}$ solar cells can be deposited from a pure $\mathrm{SiH}_{4}$ flow. We will make plausible that the previously reported drop of performance at low $R$ was in fact caused by an initial diffusion flux of $\mathrm{SiH}_{4}$ from the reactor's dead volume back into the plasma. Our findings are important from a fundamental point of view, demonstrating that the common belief that a high feed gas dilution ratio $R$ is essential for obtaining highquality $\mu \mathrm{c}-\mathrm{Si}: \mathrm{H}$ needs reinterpretation. Moreover, the newly developed process makes ultimate effective use of the $\mathrm{SiH}_{4}$ and strongly reduces the need for $\mathrm{H}_{2}$ as additional process gas, with obvious cost reduction promises for industry.

We conducted our study in the $13.56-\mathrm{MHz}$ high pressure depletion regime, which has been developed recently for parallel plate plasma reactors to allow deposition of high-quality material at high rates. ${ }^{9-11}$ The reactor used for intrinsic $\mu \mathrm{c}-\mathrm{Si}: \mathrm{H}$ deposition, described in more detail elsewhere, ${ }^{12}$ encompassed a showerhead electrode for gas injection, and consisted of a volume of 11 liter, an interelectrode distance of $1.0 \mathrm{~cm}$, and an electrode area of $150 \mathrm{~cm}^{2}$. We applied a power of $0.5 \mathrm{~W} / \mathrm{cm}^{2}$, a pressure of $10 \operatorname{Torr}\left(1.3 \times 10^{3} \mathrm{~Pa}\right)$, a

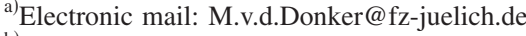

${ }^{b)}$ Electronic mail: M.C.M.v.d.Sanden@tue.nl
}

$\mathrm{SiH}_{4}$ flow of up to $3.3 \mathrm{sccm}$ (1.0 standard $\mathrm{cm}^{3} \mathrm{~min}^{-1}$, or sccm, equals $7.4 \times 10^{-7} \mathrm{~mol} \mathrm{~s}^{-1}$ ), and an $\mathrm{H}_{2}$ flow of up to $1000 \mathrm{sccm}$. The substrate was kept at $196 \pm 12{ }^{\circ} \mathrm{C}$. ${ }^{12}$ These parameters, in particular the $\mathrm{SiH}_{4}$ flow, were optimized beforehand in a deposition series ${ }^{1,5,8}$ in order to make sure that the conditions were close to the phase transition to amorphous growth. A spectrometer equipped with a chargecoupled device (CCD) camera was used to measure the time resolved emission intensities of certain spectral lines.

Figure 1(a) shows the recorded emission intensity at $414.3 \mathrm{~nm}$, originating from $\mathrm{SiH}^{*}$ created by electron impact dissociation of $\mathrm{SiH}_{4},{ }^{13}$ during the first minute after plasma ignition for various values of $R$. We also measured the emis-

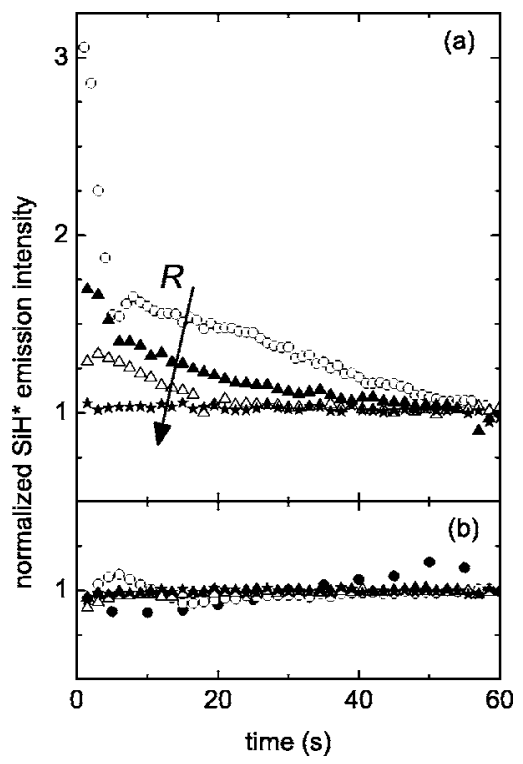

FIG. 1. Recorded $\mathrm{SiH}^{*}$ emission as function of time for various values of the $\mathrm{H}_{2}$ dilution ratio $R$, in (a) the standard process and (b) the $\mathrm{H}_{2}$ background gas condition that prevents $\mathrm{SiH}_{4}$ back diffusion. Data is shown for $R=0$ with total flow $\sim 2 \mathrm{sccm}$ (closed circles), $R=50$ with total flow $\sim 50 \mathrm{sccm}$ (open circles), $R=90$ with total flow $\sim 130 \mathrm{sccm}$ (closed triangles), $R=150$ with total flow $\sim 360 \mathrm{sccm}$ (open triangles), and $R=300$ with total flow $\sim 1000 \mathrm{sccm}$ (closed stars). In (a), the $R=0$ case could not be recorded because the plasma did not ignite. 


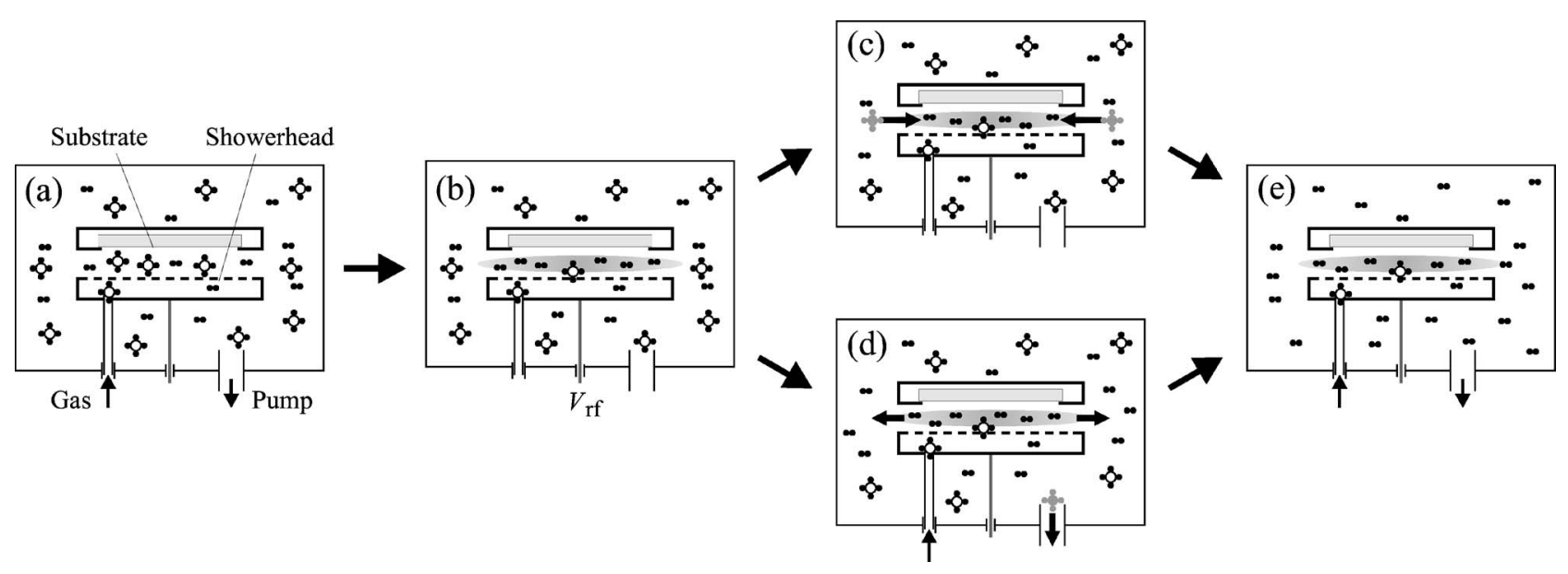

FIG. 2. Schematic representation of the sequence of processes that occur after plasma ignition: (a) stable situation before plasma ignition, (b) plasma ignition and initial $\mathrm{SiH}_{4}$ depletion in the plasma zone, (c) $\mathrm{SiH}_{4}$ back diffusion, (d) purging, (e) stable situation after plasma ignition.

sion at $390.5 \mathrm{~nm}$, originating from $\mathrm{Si}^{*}$, which showed the same behavior in all cases. One clearly observes a transient behavior; the initial $\mathrm{SiH}^{*}$ emission intensity is higher than the stable one. This effect is particularly large for low $R$, and it occurs on a typical times cale of $\sim 60 \mathrm{~s}$. Figure 1(b) shows the time-resolved optical emission intensity for a special case that will be discussed later.

We explain the transient behavior in terms of a transformation of the gas composition, as sketched in Fig. 2. Before plasma ignition [Fig. 2(a)] the entire reactor is filled with the $\mathrm{SiH}_{4} / \mathrm{H}_{2}$ gas mixture, whereas in the stable situation after plasma ignition [Fig. 2(e)] the $\mathrm{SiH}_{4}$ is heavily depleted ${ }^{8-11}$ and the reactor is predominantly filled with $\mathrm{H}_{2}$. During the transformation, the $\mathrm{SiH}_{4}$ depletion in the plasma zone [Fig. 2(b)] drives a diffusion flux of $\mathrm{SiH}_{4}$ from the reactor's dead volume back into the plasma ${ }^{14}$ [Fig. 2(c)]. A high $R$ limits the time scale on which this $\mathrm{SiH}_{4}$ back diffusion may take place by purging [Fig. 2(d)]: For the $R=0$ condition at $\sim 2 \mathrm{sccm}$ total flow we roughly estimate the gas residence time (via gas density at room temperature $\times$ reactor volume/gas flow) to be as long as $4 \times 10^{3} \mathrm{~s}$. For the $R=300$ condition at $\sim 1000 \mathrm{sccm}$ total flow, we estimate it to be only $8 \mathrm{~s}$. The $\mathrm{SiH}_{4}$ diffusion flux should be proportional to the initial $\mathrm{SiH}_{4}$ density, so this effect should be largest for low $R$. Thus, it is our tentative view that the $\mathrm{SiH}_{4}$ back diffusion is responsible for the initial enhancement and subsequent relaxation of the $\mathrm{SiH}^{*}$ emission.

Sorokin et al. ${ }^{14}$ already discussed the effect of the $\mathrm{SiH}_{4}$ back diffusion on the dust formation process in the plasma. Since our conditions are very close to the phase transition to amorphous growth, the $\mathrm{SiH}_{4}$ back diffusion mainly affects film crystallinity: Either the first minute of deposition occurs on the amorphous side of the transition, or the deposition after the first minute occurs too far inwards on the microcrystalline side of the transition. Both cases lead to poor film quality: the former because of thick amorphous incubation layers ${ }^{4,7}$ and the latter because of the too-high crystallinity. ${ }^{1}$

A background gas consisting predominantly of $\mathrm{H}_{2}$ would prevent the $\mathrm{SiH}_{4}$ back diffusion from happening. We realized this experimentally by first filling the entire reactor with $\mathrm{H}_{2}$. Then, after flushing the reactor for a short time period with the process flows of dilution $R$, the plasma was ignited. The flushing time was crucial to this method. If it was too short, a pure $\mathrm{H}_{2}$ plasma would be ignited. In this case, the $\mathrm{SiH}^{*}$ Downloaded 21 Dec 2006 to 134.94.122.39. Redistribution subject emission would gradually increase to its stable value. If it was too long, the $\mathrm{SiH}_{4}$ back diffusion process would be observed again to some degree. The time-resolved optical emission spectroscopy was used in this matter as a process control tool to determine the correct flushing times: Using values varying from $2 \mathrm{~s}$ at $R=300$ to $30 \mathrm{~s}$ at $R=0$, we obtained the stable $\mathrm{SiH}^{*}$ emission signals of Fig. 1(b). It shows only the first $60 \mathrm{~s}$ after plasma ignition, in which initial $\mathrm{SiH}^{*}$ emission enhancements of more than a factor of 2 were prevented. On longer time scales, the $\mathrm{SiH}^{*}$ emission intensity decreased further by about $20 \%$. We compensated for this by proportionally increasing the $\mathrm{SiH}_{4}$ flow during deposition.

Note that in the $R=0$ case the reactor consisted almost completely of $\mathrm{H}_{2}$ upon plasma ignition, since the flushing time was negligible compared to the gas residence time. The $\mathrm{SiH}^{*}$ emission, hence $\mathrm{SiH}_{4}$ density, remained stable at this low value after ignition notwithstanding the applied pure $\mathrm{SiH}_{4}$ flow. This confirms our previous statement about the heavy $\mathrm{SiH}_{4}$ depletion.

Solar cells are very sensitive to changes in structure or optoelectronic properties of the $\mu \mathrm{c}-\mathrm{Si}: \mathrm{H}$ film and its interfaces. Therefore, to test the $\mathrm{H}_{2}$ background condition deposited material, intrinsic $\mu \mathrm{c}-\mathrm{Si}: \mathrm{H}$ layers were incorporated in $p-i-n$ solar cell structures with an $i$-layer thickness of $1.0 \pm 0.1 \mu \mathrm{m}$. Texture-etched ZnO:Al-coated glass substrates ${ }^{15}$ served as transparent front contacts, while several $1 \times 1 \mathrm{~cm}^{2} \mathrm{Ag}$ back contacts defined the solar cell area. We applied the same deposition conditions as were used in the recording of Fig. 1(a) (the standard process) and Fig. 1(b) (the $\mathrm{H}_{2}$ background gas condition).

Figure 3 shows the solar cell properties obtained at various $\mathrm{H}_{2}$ dilution ratios $R$. For the standard process, solar cells deposited at $R<100$ showed poor performance, mainly due to lower fill factor and open circuit voltage, consistent with previous observations. ${ }^{8}$ In contrast, high-quality solar cells could be deposited at all $\mathrm{H}_{2}$ dilutions, down to $R=0$, when the $\mathrm{H}_{2}$ background gas condition was applied. We provided one sample, deposited at $0.4 \mathrm{~nm} / \mathrm{s}, R=0$, and a total gas flow of only $2.0 \mathrm{sccm}$, with a $\mathrm{ZnO} / \mathrm{Ag}$ back contact for better light trapping. The cell showed excellent electronic performance with an open circuit voltage of $564 \mathrm{mV}$ and a fill factor of $74.8 \%$. Together with the short circuit current of $22.5 \mathrm{~mA} / \mathrm{cm}^{2}$, the solar energy conversion efficiency was $9.5 \%$. Depth-profiled Raman spectroscopy measurements ${ }^{5}$
to AlP license or copyright, see http://apl.aip.org/apl/copyright.jsp 


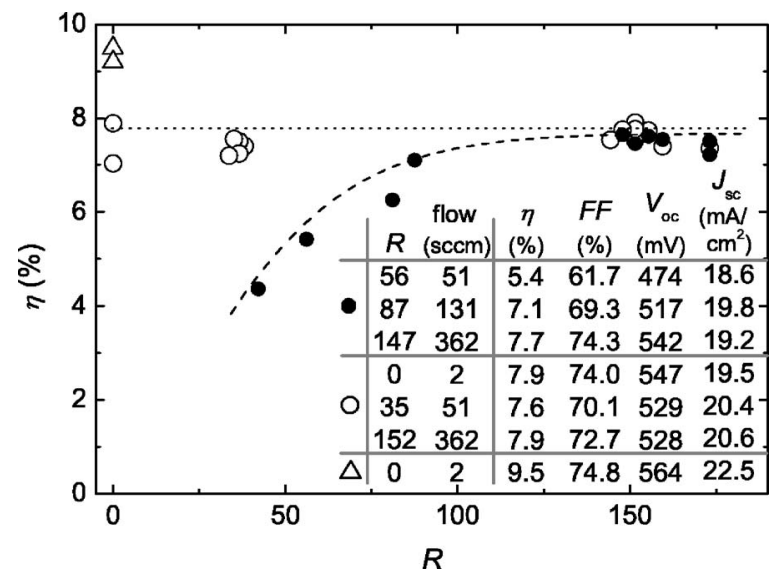

FIG. 3. Optimized solar cells deposited at various $\mathrm{SiH}_{4}$ and $\mathrm{H}_{2}$ flows represented by their efficiency $\eta$ against $\mathrm{H}_{2}$ dilution ratio $R$, for the standard process (closed circles), for the $\mathrm{H}_{2}$ background gas condition (open circles) and for the $\mathrm{H}_{2}$ background gas condition after which the solar cell was provided with a $\mathrm{ZnO} / \mathrm{Ag}$ back reflector (open triangles). The dashed and dotted lines are guides to the eye. The inset shows a table containing the dilution ratio $(R)$ and total flow for some characteristic depositions, plus the resulting solar cell parameters efficiency $(\eta)$, fill factor $(F F)$, open circuit voltage $\left(V_{\mathrm{oc}}\right)$, and short circuit current $\left(J_{\mathrm{sc}}\right)$.

revealed a homogeneously structured film crystallinity around $70 \%$.

In summary, the aforementioned results lead to a reinterpretation of the role of $\mathrm{H}_{2}$ dilution: The high $\mathrm{H}_{2}$ flow generally applied during deposition of $\mu \mathrm{c}-\mathrm{Si}: \mathrm{H}$ is needed to suppress $\mathrm{SiH}_{4}$ back diffusion. When it is suppressed in other ways, e.g., by applying a $\mathrm{H}_{2}$ background prior to plasma ignition, high-quality $\mu \mathrm{c}-\mathrm{Si}: \mathrm{H}$ can be deposited irrespective of the applied $\mathrm{H}_{2}$ flow.
The authors thank R. Schmitz, J. Klomfass, Y. Mai, and Dr. R. Carius for experimental support and fruitful discussions. Akzo Nobel NV is acknowledged for their financial support. The research of W.M.M.K was made possible by a fellowship of the Royal Netherlands Academy of Arts and Sciences (KNAW).

${ }^{1}$ O. Vetterl, F. Finger, R. Carius, P. Hapke, L. Houben, O. Kluth, A. Lambertz, A. Mück, B. Rech, and H. Wagner, Sol. Energy Mater. Sol. Cells 62, 97 (2000).

${ }^{2}$ A. Matsuda, J. Non-Cryst. Solids 59-60, 767 (1983).

${ }^{3}$ U. Kroll, J. Meier, A. Shah, S. Mikhailov, and J. Weber, J. Appl. Phys. 80, 4971 (1996).

${ }^{4}$ J. Koh, A. S. Ferlauto, P. I. Rovira, C. R. Wronski, and R. W. Collins, Appl. Phys. Lett. 75, 2286 (1999).

${ }^{5}$ Y. Mai, S. Klein, R. Carius, J. Wolff, A. Lambertz, F. Finger, and X. Geng, J. Appl. Phys. 97, 114913 (2005).

${ }^{6}$ S. Sriraman, S. Agarwal, E. S. Aydil, and D. Maroudas, Nature (London) 418, 62 (2002).

${ }^{7}$ L. Feitknecht, J. Meier, P. Torres, J. Zürcher, and A. Shah, Sol. Energy Mater. Sol. Cells 74, 539 (2002).

${ }^{8}$ T. Roschek, B. Rech, J. Müller, R. Schmitz, and H. Wagner, Thin Solid Films 451-452, 466 (2004).

${ }^{9}$ L. Guo, M. Kondo, M. Fukawa, K. Saitoh, and A. Matsuda, Jpn. J. Appl. Phys., Part 2 37, L1116 (1998).

${ }^{10}$ B. Rech, T. Roschek, T. Repmann, J. Müller, R. Schmitz, and W. Appenzeller, Thin Solid Films 427, 157 (2003).

${ }^{11}$ E. Amanitides, A. Hammad, E. Katsia, and D. Mataras, J. Appl. Phys. 97, 073303 (2005).

${ }^{12}$ M. N. van den Donker, R. Schmitz, W. Appenzeller, B. Rech, W. M. M Kessels, and M. C. M. van de Sanden, Thin Solid Films (accepted).

${ }^{13}$ F. J. Kampas and R. W. Griffith, J. Appl. Phys. 52, 1285 (1981).

${ }^{14}$ M. Sorokin, G. M. W. Kroesen, and W. W. Stoffels, IEEE Trans. Plasma Sci. 32, 731 (2004).

${ }^{15}$ O. Kluth, B. Rech, L. Houben, S. Wieder, G. Schöpe, C. Beneking, H. Wagner, A. Löffl, and H. W. Schock, Thin Solid Films 351, 247 (1999). 